\title{
Investigating and Recognizing the Effect of Mass Media on In- creased Public Understanding of Science: A Case of Isfahan Citi- zens
}

\author{
Zahra Maher $^{1}$, Ali Rabbani ${ }^{2}$ \\ IPhD candidate of sociology, University of Isfahan, Isfahan, Iran \\ 2Associate professor with the sociology department, University of Isfahan, Isfahan, Iran
}

\begin{abstract}
Upon the citizens' completion of their formal education, media become their most accessible and sometimes the only source of information on scientific achievements, debates, events and scientists' work. Science and scientists are displayed in the mass media on a day-to-day basis. People gain the major part of their knowledge on science and scientists through television and other mass media. The present study was conducted to investigate the effect of mass media on increased public understanding of science. The population of the study consisted of all Isfahan citizens aged over 15 years old. A number of 384 citizens were selected as the participants using quota sampling method. Data analysis was done using SPSS and Amos software. The results showed that the mean score of public interest in the topics of science and technology was above average. The majority of respondents had a positive attitude toward science and technology though the findings revealed that the citizens' level of scientific knowledge was below the average. Moreover, the majority of people were found to gain their understanding of science throughout their lifetime so that they collect the information necessary for this understating from an array of situations and for various reasons such as the mass media. The variable 'mass media' obtained a Gamma coefficient of 0.36 in the structural equation model and proved to exert a significant effect on the public understanding of science. The fit indices indicate that the collected data well confirmed the developed model.
\end{abstract}

Keywords: Public understanding of science, Mass media, Scientific citizen, Learning society, contextual model

\section{Introduction and statement of the problem}

The rapid development of science and technology has increased the changes in human life, complicated socio-economic systems and interwoven the various economic, social, political and technical domains. The issue of society and science or science communication is one of the major issues that has recently been raised in this domain. In this regard, research on science, technology and society focuses on the relations of science and technology with society. Over the last fifty years, social scientists and science policy makers have paid considerable attention to the relationship between science and society. However, this attention has mostly been focused on the establishment of the status of science and extension of science-based culture. Research on this topic has tried to show the importance of science for the society to achieve a higher level of welfare in order to win the social support for science and technology development programs.

One of the important issues is the communication tensions and mutual misunderstandings between scientists and the public. On the one hand, scientists and experts condemn people of misunderstanding science and technology due to the increasing specialization of science and technology and complication of the technical activities. On the other hand, the increasing penetration of science and technology into daily life and the extension of media and means of communication have increased knowledge in different social groups on the outcome of science and technology development so much so that people feel more doubt about the science, technology and their outcomes (Ghanei Rad \& Morshedi, 2011:93).

Researchers of science and society pose their specific questions to address different cognitive and attitudinal aspects of the mutual relationship between science and society: what knowledge do different groups of people have of science and technology? Are people optimistic or pessimistic about the outcomes of science and technology? What responsibility do science and its stakeholders (scientists and science policy makers) have towards society? How can one increase people's trust in science and technology and involve them in the development of science and technology? Under such circumstances, how different social groups understand science, technology and their processes has assumed great importance. This is because active participation and involvement in science and technology depends on appropriate understating of these subjects and the challenges and opportunities they create. In other words, the public may not make effective contribution to science and technology unless they have an appropriate understanding of the status of science and technology in daily life, of who the scientists are, of how science and technology develop and what hopes and fears they create for the society, 
of what role governments play in the development and control of science and technology and what relation science and technology have with social welfare.

Despite various studies on science production and its challenges in Iran, no attention has been paid to periodic survey of people's attitude and understanding of science and technology. Thus, except for one study by Ghanei Rad and Morshedi (2011), no independent study has ever investigated Iranians' understating of science and technology. Ghanei Rad and Morshedi (2011) examined Tehran citizens' understanding of science. They provided a descriptive account of their survey of the public understating of science (PUS) in Tehran citizens. They reported that the citizens' understanding of science and technology was below the average while the majority of participants had a positive attitude toward science and technology.

However, no attempt has yet been made to explain the why and how of PUS in Iran. Still, it seems that science communication researchers should base their attempts on a full analysis of where, why, when and with whom PUS and scientific learning occurs because such analysis can help researchers come across the best method of teaching science to the public. If we want to teach and transfer science effectively, we need to use methods that create enough interest in people to listen and learn. Thus, we need to know that where people are interested in learning, how they attend to the subject of interest and why they remain involved in scientific activity.

We would assert that science learning, broadly defined to include attitudinal and behavioralchange, as well as changes in conceptual understanding, is a lifelong endeavor.

Accordingly, it is fair to assume that the majority of the public constructs much of its understanding of science over the course of their lives, gathering information from many places and contexts, and for a diversity of reasons. . However, even more common is the science people learn while engaged in personal investigations, through civic organizations and active leisure pursuits, watching nature or science specials on television, using the Internet to access science-, environmental- or health-related information, and engaging in science- related hobbies and special interest groups (Anderson, 1999; Anderson et al., 2000; Falk, 2002; Falk and Dierking, 1992,2000, 2002).

Indeed, the significance of the media in informing the public about science cannot be overlooked. When formal education in science ends, media become the most available and sometimes the onlysource for the public to gain information about scientific discoveries, controversies, events, and the work of scientists. Science and scientists are portrayed in the mass media on a dailybasis . It is through television and other mass media that individuals receive much of their knowledge about science and scientists (Gerbner et al., 1981; LaFollette, 1990; Nelkin, 1995).

Although theremaybe other important sources of scientific information- science classes, science museums, and interpersonal sources would be three examples - no other source offers as much access to scientific information as do the mass media.Newspapers and magazines, especiallytec hnical or scientific publications, even within the popular press, offer rich sources for learning about scientific practices and advances. Television, perhaps, offers the best possibilities for broad access to various publics; given that people are spending a significant amount of time with television compared to other media, one might expect television to provide the most opportunityfor educational gains in terms of science knowledge. In the past, well-known scientists such as astronomer Carl Sagan and Nobel laureate Leon Lederman(Pollack, 1998) advocated that television holds vast potential for teaching mass audiences about science. In fact, some surveystudies with children have shown television science programming to be effective in teaching children science content (Fortner, 1986; Gunter, Clifford,\&McAleer, 1997; Mares \& Cantor, 1999) .

The present study first presents a theoretical discussion on public understanding of science. Then the specific analytical model of the study would be presented. The study aims to explain PUS by using contexual approach (Martin, 2003; Halford, 2006; Schuetze, 2007; Delanty, 2003). In this approach, science learning through mass media, which people do selectively and freely, plays an important role in PUS. Thus, science learning is considered as part and parcel of daily life and the natural result of living in a world fraught with science. In other words, science learning is an important by-product of living in the contemporary society (Falk \& Dierking, 2002).

In this regard, the present study primarily aims to examine the role of mass media in increased public understating of science and technology. Besides this primary goal, the study also pursues the following goals:

- $\quad$ Investigating PUS and its dimensions among Isfahan citizens

Investigating how much citizens use scientific mass media

Suggesting approaches to improving PUS in the research population based on the independent variable

\section{Theoretical framework}

In this section, we would review the main theoretical frameworks of the relationship between science and society or the evaluation of people's knowledge and attitude towards science and technology. 


\section{2-1-Public understanding of science}

\section{2-1-1- traditional perspective: deficite model}

The traditional, positivist approach tends to conduct large-scale surveys in order to measure public understanding of science (PUS). This approach functions based on what has been called the deficit model (Miller, 1987, 1988, 2001). The deficit model pictures people as the passive consumers of science. In this regard, people always fall behind valid scientific knowledge. Hence, this knowledge deficit should be amended in people. Deficit model has been supported by thousands of international surveys. Research findings have shown that the majority of people are disinterested or illiterate in science (National Science Board, 1998, 2000, 2002, 2004). For example, American adults had poor performance in national tests of scientific knowledge and only those who had passed scientific courses at university could do well in the tests (Miller, 1987, 1998, 2001; Miller \& Pifer, 1996). Thus, the government should take measures to increase citizens' scientific literacy as the science develops. Consistent with these attempts and their importance in science-society relations, scientific literacy came into vogue as a dominant discourse in the 1960s-1980s.

For a long time, the main focus of PUS was on the notion of scientific literacy as a set of scientific knowledge and abilities described historically as a combination of science, scientific activities and mental habits (American Association for the Advancement of Science, 1994; Brown, Reveles \& Kelly, 2005; National Science Board, 1996). Scientific literacy is a key component of a democratic society that supports a modern, technological economy and encourages cultural values. It is generally held that a scientifically-literate society is more likely to understand science-based general political discussions and consequently support more rational policies emerging from public debates. It is also held that a scientifically-literate society creates a culture of science and technology. This makes students choose the science- and technology-based jobs in order to contribute to national economy and business (Miller, 2001; Kleinman \& Powell, 2007). In a genealogic view, Bauer, Allum and Miller (2006) consider that such understanding of scientific literacy originates from the concept of political literacy. That is, just as people can participate in democratic processes by only acquiring political literacy, they can act as the supporters of science by developing a certain level of scientific knowledge.

In early stages, little importance was attached to people's attitude toward science in developing scientific literacy so that literacy was measured based on 'knowledge of facts' and 'knowledge of scientific methods'. However, it was not until two decades when the measurement of people's attitude toward science gained gradual importance. Morris Shamos is one of the most prominent critics of scientific knowledge. Shamos (1995) contends that scientific knowledge was a pointless myth and an unattainable goal. Like Rousseau, he addressed the confusion of educational system in human education as a transcendental goal and citizen education as a goal to manage social affairs. He voiced a set of criticisms around this key distinction (Shamos, 1995). Other critics (Bauer, Allum \& Miller, 2006) have observed that everybody suffers a certain degree of scientific knowledge deficit based on scientific literacy paradigm. However, one should call the excessive importance of scientific literacy into doubt where other forms of knowledge such as historical and legal literacies assume greater significance. Emphasizing the fundamental importance of contextual knowledge, other critics (Wynne, 1991, 1992, 1995) consider that the conceptualization of scientific literacy depends upon studies on social-anthropological variables. In this regard, indicators of scientific literacy are considered as abstract concepts that produce wrong results in empirical measurement since they disregard the contextual significance of literacy.

As discussed, research has shown that the general public is disinterested and illiterate in science. The deficit perspective has been supported continually in thousands of international surveys. About half a century of attempts and billions of dollars on modification of scientific education have only resulted in small changes in the scores of people's scientific knowledge (Kretzmann \& McKnight, 1993). I think this is the result of the weaknesses of the deficit model. Therefore, another approach should be taken to assessing PUS.

\section{2-1-2-A New perspective: : the emergence of Contextual model}

This model tends to examine the cultural contexts of PUS. In this approach, all types of knowledge including specialized and public knowledge are organized around social, cultural and local conditions. It illustrates the relationship of science and society as two concentric circles where a broader culture embodies science. Based on the contextual model, scientific learning is the natural result of living in a world rich in knowledge that flows in daily life. Alternatively referred to as 'social-cultural', this approach posits that, like other types of learning, science learning is associated with the individuals' need for understanding. In this regard, every individual may have a unique repertoire of knowledge - a certain level of scientific knowledge determined by personal needs, abilities and social-historical context. In this approach, PUS is not considered as a general set of knowledge and skills a citizen should acquire to a certain age; rather, it is characterized as a set of knowledge and skills that people develop in their lifetime (Wynne, 1991; Michael, 1996, 1998, 2002).

Similarity of scientific knowledge in people may be associated with their convergence in life experiences, occupation, hobbies and interests but not in their similar level of education. Every individual develops an understanding of a certain area of science which is consistent with his unique personal needs and interest to 
learn that scientific area. Thus, scientific knowledge is variable and specific but not broad and general. For example, research has shown that amateur astronauts develop a considerable body of knowledge on astronavigation as a result of several years of membership in clubs and public relief activities rather than official education in astronavigation (Berendsen, 2003, 2005). Alternatively known as 'lifelong learning', this approach does not consider learning as the conventional process of acquiring science but as a lifelong, unique and personal process. In this regard, the bulk of our learning is not compulsory but based on free choice because our life events inherently drive us toward more learning while part of our learning is accidental without intentional planning.

Originally, this concept implicates a new kind of society in which the traditional distinction between formal and informal education no longer counts. In this new context, lifelong learning is inevitable because people often have to change workplaces or jobs and update their knowledge in their career. In addition, learning is not an advantage of the elite or a specific age group; rather, this idea covers all communities and age groups (Vallima \& Halfman, 2008).

\section{2-1-3- How mass media contribute to PUS: Actor-network theory and translation process}

Actor-network theory, also referred to as enrollment theory, was developed based on the works of Bruno Latour and Michel Callon, French scholars of science and technology, and John Law, the British anthropologist, in the mid-1980s. In terms of genealogy, actor-network theory appears to be a unique and subtle blend of Foucault's theory of power knowledge and material semiotics, Deleuze and Gataz's ideas (particularly the concept of assemblage) as well as social realism and structuralism, which provide a modern theoretical and conceptual framework to perceive collective social-technical processes and intellectual and practical movements. This theory focuses on the networks of science and technology (Ghazi Tabatabaie \& Vadadhir, 2007). It suggests that the appropriate method of studying science is one that pursues and describes what the scientists actually do in practice: their interactions with other actors, both human and non-human, who are enrolling. ANT actors are the activists or agents .

An actor is not an entity to whom purposeful human behaviors can be attributed; rather, it is a far more abstract concept that can address both human and non-human identities. Actors join and derive their identities from networks. On the other hand, they turn into networks over the course of their scientific work. They develop as networks. Indeed, this theory disregards the distinction between agency and structure and links the actor and network (Ghazi Tabatabaie, 2007:135).

An actor-network exists when a collection of interrelated entities are successfully enrolled by an actor so that the actor can act on behalf and by support of the entities. Translation process is a process whereby an actor enrolls (enlists) other entities. The important characteristic of actor-network theory in the theoretical framework of this article lies in that it puts considerable ontological emphasis on the active role of non-human world in shaping interactions and communications. That is, actors are not only humans; rather, as Latour(1999) contends, an actor or agency is anything: a car, an animal, a text, all these together or anything else. In this theory, the network is realized in a heterogeneous blend of textual, conceptual, social and technical actors. Actors are a synthesis of things, identities and symbolic writings that can enter different networks.

Media are considered as the network actors whose role is to mediate between science and the public. They mediate actors in the science and public domain and help control or coordinate their interactions (combined relationship) effectively (Latour,2005). In order for the media to create a constructive interaction between science and the public, they need to play a mutual mediatory role in constructing communication texts. To this end, on the one hand, the media need to represent the content of the texts according to the actors' characteristics and interests. On the other hand, the content of communication texts should affect the method and quality of inter-actor interactions. In an ideal condition, the media (media institution/media actors) construct and make the messages intelligible consistent with the characteristics of their audience through recognizing those characteristics. Appropriate presentation of a message by media makes it intelligible. Here, the message presenter serves two important roles: first, it should understand and translate what experts have produced in science, and second, it should translate the specialized message into lay words to convert the specialized science into public science. Latour (2005:225) considers that media need to transform, convert or translate the science in order to transfer it to the public.

\section{Analytical model and research hypotheses}

The study mainly focuses on PUS as one of the primary steps taken to measure the relationship between science and society. We have addressed this topic due to the high importance attached to this issue in international studies and its relevance to current situation in Iran. In our society, we may not still talk of the people's involvement in the decision-making, policy-making and planning process of science and technology in the true sense of the word. Thus, the present study focuses on the PUS theoretical model (contextual model). 
The study aims to determine PUS with an emphasis on the role of mass media. In this regard, science learning through mass media, to which people turn voluntarily, plays an important role in PUS.

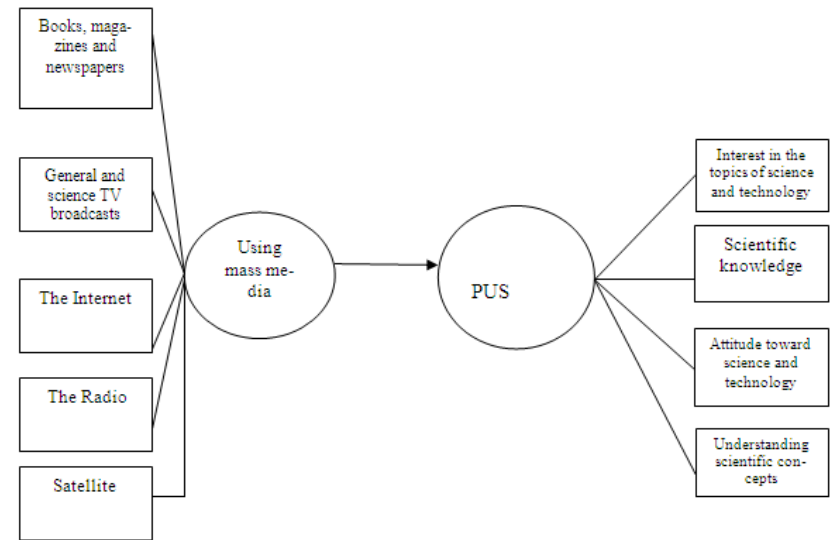

Figure 1. Analytical model of the research

In other words, science learning is the by-product of living in the contemporary society (Falk \& Dierking, 2002). Considering the theoretical design of the research, the present study aims to examine the role of freechoice learning (through mass media) in increased public understanding of science and technology. Thus, the main research hypothesis is as follows:

- $\quad$ There is a significant positive correlation between the amount of mass media use and public understating of science (PUS).

\section{Methodology}

In this section, the key terms would be defined first based on the analytical model. Then, the research instrument and its reliability and validity would be examined. Finally, the research methodology and sampling procedure are delineated.

\section{4-1- Definition of the key concepts}

\section{- Public understating of science (PUS)}

PUS refers to an investigation of scientific knowledge and public attitude (including the concerns, hopes and fears) towards science and technology (National Science Board, 1998). The dimensions of PUS including (1) interest in the topics of science and technology, (2) understating scientific concepts, (3) level of scientific knowledge, and (4) attitude towards science and technology were determined based on the international research in different countries as well as the survey conducted in Tehran, Iran (Ghanei Rad \& Morshedi, 2011). Questionnaire items were developed in order to examine these dimensions consistent with the specific conditions in Iran.

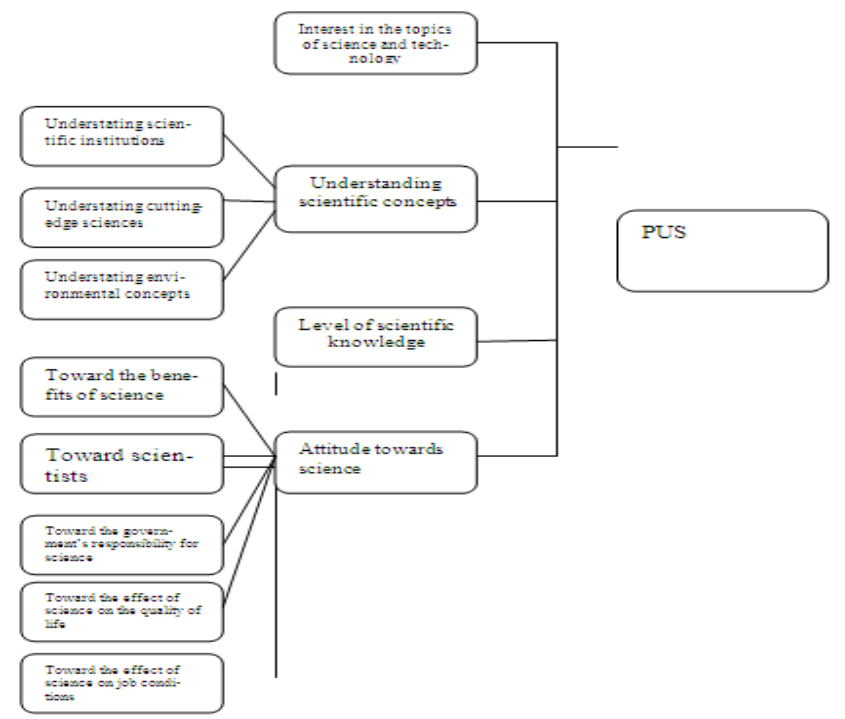

Figure 2. Dimensions of PUS 


\section{- Interest in the topics of science and technology}

This variable aims to measure the respondents' knowledge of science and technology. To this end, the respondents' knowledge was evaluated by addressing six subject areas including new scientific discoveries, application of new technological inventions, computer technology, application of nuclear energy, space explorations, and national policies of science and technology. The respondents were to report their knowledge of every subject area by checking one of the alternatives ranging from Nothing to Very Much. Thus, the questionnaire items addressing the respondents' interest in the topics of science and technology were on a 5-point Likert scale ranging from Nothing (1) to Very Much (5).

\section{- Understanding scientific concepts}

Together with its three subscales, this variable evaluates the respondents' knowledge of 'scientific and technological processes and institutions' such as science and technology parks, research towns, growth centers, research and development, research centers, think tank, market technique, intellectual property, patents, research commercialization, transfer of technology, national system of innovation, knowledge-based development, information society; 'knowledge of cutting-edge science and technology' such as IT, nanotechnology, cognitive sciences, genetic engineering, cloning; and 'knowledge of environmental concepts' such as acid rain, ozone gap, environmental contamination, global warming, and greenhouse gases. The respondents' knowledge of the above subjects was measured on a 4-point Likert scale ranging from At All (1) to A Lot (4).

\section{- Level of scientific knowledge}

A number of 12 scientific items were presented to the respondents in order to measure their level of scientific knowledge. The respondents were asked to check the items either true or false (see Table 3). Besides, they could also check 'I don't know' on every item. In order to develop an index of the respondents' level of scientific knowledge, every correct answer received a score of 1 and every incorrect answer was given zero.

\section{- Attitude toward science and technology}

Attitude refers to the positive or negative perceptions of a certain issue, which typically involves cognitive, affective and behavioral dimensions of the issue in a complicated manner. A number of 20 items were developed to examine the respondents' attitude toward science and technology. Every item measures the respondents' positive or negative attitude toward different categories of science and technology (see Table 4). In order to compute the total scores, every respondent was given 5 points for agreement with a positive item and disagreement with a negative item. On the other hand, they were given 1 point for disagreement with every positive item and agreement with every negative item. The total scores were obtained by adding up the individual scores on the 20 items.

\section{- Mass media}

This variable was to measure how much the respondents used mass media to obtain scientific information. To this end, a list of mass media including non-academic books, magazines, newspapers, the radio, satellite, the Internet, general and science TV broadcasts were presented to the respondents. Then they were asked to determine how much they gained their scientific knowledge from every source. The respondents checked one of the alternatives (at all, low, somewhat, and a lot) to report what part of their scientific knowledge they gained from every source (see Table 6). The scores on every item ranged from 1 (at all) to 4 (a lot). The total score of every respondent on this variable was obtained by adding up the individual scores on every item.

\section{4-2. Instrument and data analysis}

The data was collected by using systematic interview method in the form of a questionnaire with closed-ended questions.

\section{4-3- Reliability and validity of the questionnaire}

The content validity of the questionnaire was assessed in three stages:

1. Reviewing the theoretical and empirical background of every latent variable and determining its dimensions

2. Formulating questions to examine the dimensions of the variables and choosing a select number of questions (sampling validity)

3. Approval of the select questions by a few sociologists and experts (face validity)

Thus, the theoretical and empirical background of every latent variable (i.e. PUS and using mass media) was fully studied in order to determine their dimensions. For example, the measurement scale of the variable 'using mass media' was developed based on the previous studies on this topic. The same procedure was followed for the variable 'PUS'. Then, questions were developed to measure every dimension. Subsequently, a 
number of questions were selected as the sample to represent the whole questions (sampling validity). The scale developed for every latent variable was then given to a few experts for assessment and approval.

Besides, confirmatory factor analysis was used to measure the construct validity of the variable 'using mass media' and every dimension of PUS separately using Amos software. In the confirmatory factor analysis models, the significance of the observed coefficients on the latent variable ( $t$ value greater than 1.96) and the acceptable fit indices are considered as the validity for the measurement scale. From among different fit indices, chi-square (CIMN), normed chi-square, comparative fit index (CFI) and root mean squared error of approximation (RMSEA) were examined in the present study (Ghasemi, 2010). In this study, the goodness of fit of the model was conditioned on a normed chi-square index of 1 to 5 , a CFI of 0.90 or more, and an RMSEA of 0.08 or less while chi-square index should not be significant as an index of the badness of fit.

The reliability of the variables and their dimensions was calculated using Cronbach's alpha formula. The minimum acceptable alpha coefficient was considered to be 0.70 in order to confirm the reliability of the variables. Following the assessment of the validity and reliability of the instrument, changes were made in how the variables were measured due to the significance of factor loadings, fit index values and alpha coefficient values. In testing the validity of the variables, confirmatory factor analysis revealed that the factor loadings of some items or statements were small and insignificant, which decreased the coefficients of the model. Thus, these items were eliminated from the instrument. In some subscales such as the subscales of the respondents' attitude toward science and technology, the Cronbach's alpha coefficients were less than satisfactory; thus, the reliability of the scale was unacceptable. Therefore, the items that were responsible for small coefficients were omitted from the instrument. Finally, the reliability and validity of the questionnaire showed acceptable indices after making the necessary amendments as summarized in Table 1.

Table 1. Validity and reliability of the scales

\begin{tabular}{|c|c|c|c|c|c|c|c|c|c|c|c|}
\hline $\begin{array}{l}3 \\
\Xi \\
\Xi \\
\vdots \\
8\end{array}$ & 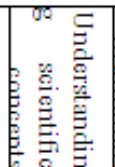 & 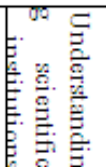 & 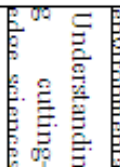 & 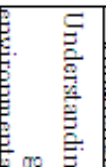 & 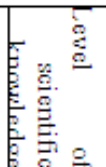 & 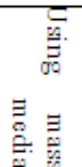 & 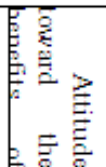 & 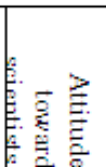 & 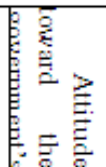 & 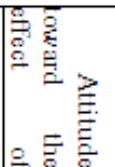 & 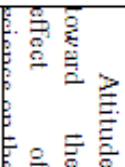 \\
\hline CMN/DF & 2.03 & 2 & 2.04 & 3.01 & 1.08 & 1.04 & 2.06 & 4.01 & 3.61 & 2.45 & 3.41 \\
\hline CFI & 0.94 & 0.91 & 0.91 & 0.89 & 0.97 & 0.96 & 0.90 & 0.88 & 0.91 & 0.95 & 0.90 \\
\hline RMSEA & 0.05 & 0.03 & 0.05 & 0.07 & 0.02 & 0.02 & 0.04 & 0.05 & 0.07 & 0.02 & 0.02 \\
\hline$\alpha$ & 0.69 & 0.71 & 0.70 & 0.73 & 0.68 & 0.72 & 0.84 & 0.75 & 0.69 & 0.73 & 0.78 \\
\hline
\end{tabular}

\section{4-4) Population and sampling method}

The population of the study consisted of all Isfahan citizens aged 15 years and older. The sample size was calculated based on the indices $\mathrm{t}=1.96, \mathrm{P}=0.05$ and $\mathrm{q}=0.5$ using Cochran's formula. The sampling was carried out by gender and address using quota sampling. The distribution of the population was remodeled in a smaller size based on the sample size. Then the total number of individuals in any population unit was divided by the total population. The obtained value was multiplied by the sample size in order to allocate a certain number to every population unit. Eventually, a number of 384 questionnaires were administered to the participants.

\section{5-1) Interest in the topics of science and technology}

\section{Results}

The respondents' interest in science and technology was above average across the six subject areas. The respondents reported their greatest interest to be in the application of nuclear energy $(M=4.2)$ and their slightest interest in space explorations $(\mathrm{M}=3.01)$ on a scale of 1-5. Other subject areas fell in between including application of new technological inventions $(\mathrm{M}=3.9)$, computer technology $(\mathrm{M}=3.6)$ and national policies of science and technology $(\mathrm{M}=3.2)$.

\section{5-2) Understanding scientific and technological concepts}

The respondents had little knowledge of scientific processes and institutions so that over $80 \%$ of the respondents had no knowledge of such institutions as market technique, growth centers, think tank, intellectual property, and national system of innovation. In the realm of scientific processes and institutions, the respondents were most familiar with research towns and least familiar with market technique. They had average knowledge of cutting-edge science and technologies such that the mean scores of their knowledge of genetic engineering and cloning, nanotechnology, and IT were 1.98, 2.09 and 2.16, respectively, in an ascending order on a scale of 1-4. The respondents had an above average knowledge of environmental concepts. They had more information on environmental contamination $(\mathrm{M}=2.79)$ and global warming $(\mathrm{M}=2.63)$ than on greenhouse gases $(\mathrm{M}=2.3)$, ozone gap $(\mathrm{M}=2.1)$ and acid rain $(\mathrm{M}=1.94)$. 
Table 2. Respondents' knowledge of scientific concepts

\begin{tabular}{|c|c|c|c|c|c|c|c|}
\hline No. & Dimension & Subset & $\stackrel{p}{\circ}$ & 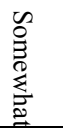 & 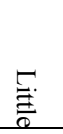 & 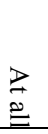 & \begin{tabular}{l}
3 \\
$\mathbb{8}$ \\
\hdashline
\end{tabular} \\
\hline 1 & \multirow{12}{*}{$\begin{array}{l}\text { knowledge of } \\
\text { scientific and } \\
\text { technological } \\
\text { processes and } \\
\text { institutions }\end{array}$} & $\begin{array}{rr}\text { Science } & \text { and } \\
\text { technology } & \text { parks } \\
\end{array}$ & 11 & 9 & 18 & 62 & 1.69 \\
\hline 2 & & Research towns & 21 & 15 & 32 & 32 & 2.25 \\
\hline 3 & & Growth centers & 2 & 8 & 2 & 88 & 1.24 \\
\hline 4 & & Research centers & 14.33 & 10.3 & 18.2 & 57 & 1.81 \\
\hline 5 & & Think tank & 3.75 & 10 & 1.25 & 85 & 1.32 \\
\hline 6 & & Market technique & 3 & 2.5 & 3.5 & 91 & 1.17 \\
\hline 7 & & Intellectual property & 4.5 & 7.3 & 6.2 & 82 & 1.34 \\
\hline 8 & & $\begin{array}{r}\text { Patents } \\
\end{array}$ & 13.3 & 20.2 & 26.2 & 40 & 2.06 \\
\hline 9 & & $\begin{array}{lr}\text { Transfer } & \text { of } \\
& \text { technology } \\
\end{array}$ & 8 & 12 & 10 & 70 & 1.58 \\
\hline 10 & & $\begin{array}{ll}\text { National } & \begin{array}{l}\text { system of } \\
\text { innovation }\end{array} \\
\end{array}$ & 4.7 & 6.8 & 8.5 & 80 & 1.36 \\
\hline 11 & & $\begin{array}{r}\text { Knowledge-based } \\
\text { development }\end{array}$ & 8.9 & 9.1 & 32 & 50 & 1.76 \\
\hline 12 & & Information society & 12 & 10 & 36 & 42 & 1.9 \\
\hline 13 & \multirow{3}{*}{$\begin{array}{l}\text { knowledge of } \\
\text { cutting-edge } \\
\text { science and } \\
\text { technologies }\end{array}$} & IT & 17.5 & 11 & 41.5 & 30 & 2.16 \\
\hline 14 & & Nanotechnology & 16 & 13 & 35 & 36 & 2.09 \\
\hline 15 & & $\begin{array}{rr}\text { Genetic engineering } \\
\text { and cloning }\end{array}$ & 7 & 12 & 53 & 28 & 1.98 \\
\hline 16 & \multirow{5}{*}{$\begin{array}{r}\text { knowledge of } \\
\text { environmenta } \\
1 \text { concepts }\end{array}$} & Acid rain & 11.2 & 17 & 26.8 & 45 & 1.94 \\
\hline 17 & & Ozone gap & 25.5 & 34 & 30.5 & 10 & 2.1 \\
\hline 18 & & $\begin{array}{c}\text { Environmental } \\
\text { contamination }\end{array}$ & 24.5 & 42 & 31.5 & 2 & 2.71 \\
\hline 19 & & Global warming & 22 & 51 & 15 & 12 & 2.63 \\
\hline 20 & & Greenhouse gases & 46 & 12.5 & 16.5 & 25 & 2.3 \\
\hline
\end{tabular}

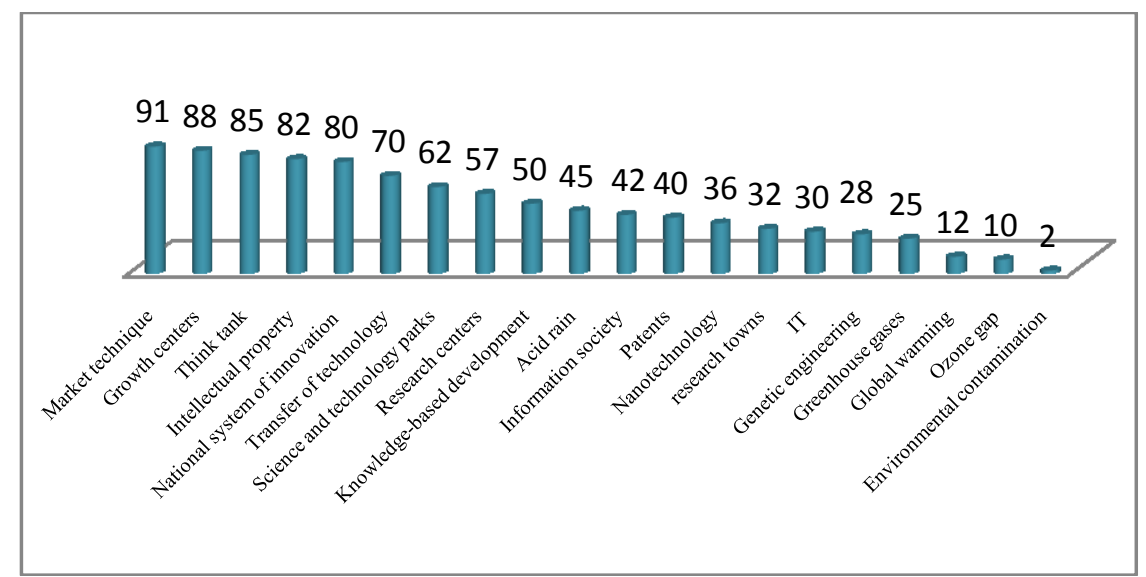

Figure 3. Percentage of deficient knowledge of scientific and technological concepts

\section{5-3) Level of scientific knowledge}

Considering the mean score of the respondents' correct answers to 13 items on the questionnaire, the level of scientific knowledge in Isfahan citizens was found to be 37.3 out of 100 . A relatively higher percentage of respondents could provide the more-general third, ninth and twelfth items with correct answers. However, the tenth, seventh, eleventh and fifth items, which are related to technical or historical subjects, received few correct responses (see Table 3).

Table 3. Respondents' level of scientific knowledge

\begin{tabular}{|c|c|c|c|c|c|}
\hline $\begin{array}{l}\text { Z } \\
\text { ? }\end{array}$ & & Item & $\vec{\Xi}$ & $\begin{array}{l}T \\
0 \\
0 \\
0 \\
0\end{array}$ & 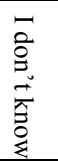 \\
\hline 1 & The center of the Earth is very hot (True) & & 38.2 & 18.3 & 43.5 \\
\hline 2 & Light travels faster than sound (True) & & 35.2 & 12.2 & 52.6 \\
\hline 3 & Food additives cause cardiac diseases (True) & & 69.9 & 13.7 & 16.4 \\
\hline 4 & Father genes determine the baby's sex (True) & & 41 & 20 & 39 \\
\hline
\end{tabular}


Investigating and Recognizing the Effect of Mass Media on Increased Public Understanding .....

\begin{tabular}{|c|c|c|c|c|}
\hline 5 & Lasers work with a synthesis of sound waves (False) & 20 & 19.1 & 60.9 \\
\hline 6 & Electrons are smaller than atoms (True) & 21.5 & 40.5 & 38 \\
\hline 7 & The universe was started out of an explosion (False) & 15 & 13 & 72 \\
\hline 8 & $\begin{array}{l}\text { The continents have been moving over millions of years and will continue to move } \\
\text { in future (True) }\end{array}$ & 55.2 & 13.5 & 31.3 \\
\hline 9 & Smoking causes lung cancer (True) & 60.9 & 18.7 & 20.4 \\
\hline 10 & Primitive humans lived during the age of dinosaurs (False) & 20 & 10 & 70 \\
\hline 11 & $\begin{array}{l}\text { When milk is contaminated with radioactive rays, it can be safe to drink after } \\
\text { boiling (False) }\end{array}$ & 20 & 15 & 65 \\
\hline 12 & The earth orbits the sun (True) & 65.9 & 15.7 & 18.4 \\
\hline 13 & Sunlight causes skin cancer (True) & 40 & 28 & 32 \\
\hline
\end{tabular}

\section{5-4) Attitude toward science and technology}

A number of 20 items on the questionnaire were developed to examine the respondents' attitudes toward the five dimensions of science and technology. Accordingly, positive and negative attitudes were measured each with 10 items. The mean score of the respondents' attitude was 4.02 on a scale of 1-5. This suggests that the majority of respondents had a positive attitude toward science and technology. The results revealed that they took the most positive attitude toward the government's responsibility for science $(\mathrm{M}=4.01)$ and the effect of science on job conditions $(\mathrm{M}=4.47)$. They also reported to have a positive attitude toward scientists $(M=4.01)$, the benefits of science $(M=3.9)$ and the effect of science on the quality of life $(M=3.74)$ (see Table 4 and Table 5).

Table 4. Respondents' distribution by their attitude toward science and technology (\%)

\begin{tabular}{|c|c|c|c|c|c|c|c|c|}
\hline \multirow[t]{2}{*}{ No. } & \multirow[b]{2}{*}{ 焉 } & \multirow[b]{2}{*}{ Items } & \multicolumn{5}{|c|}{ The degree of (dis) agreement (\%) } & \\
\hline & & & 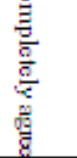 & 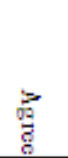 & 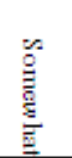 & 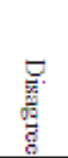 & $\frac{\frac{\rho}{g}}{\frac{0}{3}}$ & $\frac{3}{\frac{3}{3}}$ \\
\hline 1 & \multirow{5}{*}{$\begin{array}{r}\text { Attitude } \\
\text { toward } \\
\text { the } \\
\text { benefits } \\
\text { of science }\end{array}$} & $\begin{array}{l}\text { Scientific research has more disadvantages than ach antages (nee- } \\
\text { ative) }\end{array}$ & 3.8 & 8.3 & 29.3 & 31.2 & 27.4 & 3.7 \\
\hline 2 & & $\begin{array}{l}\text { Science is important per se regardless of its benefits and applica- } \\
\text { tions (positive) }\end{array}$ & 49.7 & 26.1 & 17.2 & 5.1 & 1.9 & 4.16 \\
\hline 3 & & $\begin{array}{l}\text { If scientific and technological development leads to adverse } \\
\text { outcomes, new discoveries will be made to eliminate those out- } \\
\text { comes (positive) }\end{array}$ & 42.7 & 38.9 & 14.6 & 2.5 & 1.3 & 4.19 \\
\hline 4 & & $\begin{array}{l}\text { The advantages of space exploration is greater than its costs } \\
\text { (positive) }\end{array}$ & 31.2 & 35 & 24.2 & 9.6 & - & 3.78 \\
\hline 5 & & $\begin{array}{l}\text { The costs of TV broadcasts on space exploration are more than } \\
\text { their benefits (positive) }\end{array}$ & 2.5 & & 25.5 & 40.1 & 24.8 & 3.7 \\
\hline 6 & \multirow{4}{*}{$\begin{array}{r}\text { Attitude } \\
\text { toward } \\
\text { scientists }\end{array}$} & Scientists do not usually get married (negative) & 1.9 & 8.9 & 31.2 & 33.8 & 24.9 & 3.69 \\
\hline 7 & & $\begin{array}{l}\text { Scientists do not have enough time for their family and children } \\
\text { (negative) }\end{array}$ & 6 & 13 & 46 & 49 & 43 & 3.7 \\
\hline 8 & & Scientists typically are not religious (negative) & 1.9 & 2.5 & 10.8 & 33.8 & 51 & 4.29 \\
\hline 9 & & Scientists have a dangerous power (negative) & 2.8 & 4.8 & 12.3 & 12.3 & 68 & 4.38 \\
\hline 10 & \multirow{2}{*}{$\begin{array}{l}\text { Governm } \\
\text { ent's } \\
\text { responsibi } \\
\text { lity for } \\
\text { science }\end{array}$} & $\begin{array}{l}\text { The government should grant subsidy to scientificrearch (posi- } \\
\text { tive) }\end{array}$ & 69 & 17.8 & 9 & 2.5 & 1.8 & 4.49 \\
\hline 11 & & $\begin{array}{l}\text { The government should support scientific projects in order to } \\
\text { increase human knowledge even if they haveno immediate bene- } \\
\text { fit (positive) }\end{array}$ & 57.3 & 14.3 & 13.8 & 7 & 7.8 & 4.6 \\
\hline 12 & \multirow{3}{*}{$\begin{array}{l}\text { The effect } \\
\text { of science } \\
\text { on job } \\
\text { conditions }\end{array}$} & $\begin{array}{l}\text { Using new science and technologies makes the routine work } \\
\text { more attractive (positive) }\end{array}$ & 71.5 & 19 & 4.8 & 2.8 & 2 & 4.55 \\
\hline 13 & & $\begin{array}{l}\text { Scientific and technological development leads to the workers } \\
\text { unemployment (negative) }\end{array}$ & 5.8 & 2.5 & 5 & 18 & 68.8 & 4.41 \\
\hline 14 & & $\begin{array}{l}\text { Scientific and technological development provides thenew gen- } \\
\text { eration with better job conditions (positive) }\end{array}$ & 68 & 18 & 7.5 & 4.5 & 2 & 4.45 \\
\hline 15 & \multirow{6}{*}{$\begin{array}{l}\text { The effect } \\
\text { of science } \\
\text { on the } \\
\text { quality of } \\
\text { life }\end{array}$} & $\begin{array}{l}\text { Scientific and technological development increases personal } \\
\text { enjoyment of life (positive) }\end{array}$ & 78 & 14 & 5 & 1.8 & 1.3 & 4.65 \\
\hline 16 & & Techno logical developments damage the environment (negative) & 20.5 & 19.2 & 57.2 & 2 & 1 & 2.35 \\
\hline 17 & & $\begin{array}{l}\text { Technological developments propagate non-humane way of ife } \\
\text { (negative) }\end{array}$ & 20.5 & 17.5 & 60.9 & 0.3 & 0.7 & 2.37 \\
\hline 18 & & $\begin{array}{l}\text { Scientific and technological development contributes to giobal } \\
\text { peace (positive) }\end{array}$ & 57.3 & 14.5 & 9.8 & 11.3 & 8.3 & 4.03 \\
\hline 19 & & $\begin{array}{l}\text { Scientific and technological development woud guarantee public } \\
\text { health (positive) }\end{array}$ & 74.3 & 17 & 5.8 & 2 & 1 & 4.61 \\
\hline 20 & & $\begin{array}{l}\text { Scientific and technological development increases livingcosto } \\
\text { (negative) }\end{array}$ & 12.3 & 3.5 & 6.8 & 25 & 63.5 & 4.46 \\
\hline
\end{tabular}


Table 5. Mean scores of the attitude toward science and technology and its dimensions (1-5 scale)

\begin{tabular}{|r|r|r|r|r|r|r|}
\hline & $\begin{array}{r}\text { Attitude toward } \\
\text { science } \begin{array}{r}\text { and } \\
\text { technology }\end{array}\end{array}$ & $\begin{array}{r}\text { Attitude toward } \\
\text { the benefits of } \\
\text { science }\end{array}$ & $\begin{array}{r}\text { Attitude toward } \\
\text { the scientists }\end{array}$ & $\begin{array}{r}\text { Attitude toward } \\
\text { the } \\
\text { government's } \\
\text { responsibility } \\
\text { for science }\end{array}$ & $\begin{array}{r}\text { Attitude toward } \\
\text { the effect of } \\
\text { science on job } \\
\text { conditions }\end{array}$ & $\begin{array}{r}\text { Attitude toward } \\
\text { the effect of } \\
\text { science on one } \\
\text { quality of life }\end{array}$ \\
\hline Mean & 4.02 & 3.90 & 4.01 & 4.54 & 4.47 & 3.74 \\
\hline
\end{tabular}

\section{5-5) Using mass media}

A list of mass media was presented to the respondents to measure how much they used different media. They were asked to determine how much they obtained their knowledge and scientific information from every source. To this end, they had to select one of the alternatives: at all, little, average and a lot. According to the data presented in Table 6 , the mean score of mass media use on a scale of $1-4$ was 2.5 , that is slightly above the average. General and science TV broadcasts had the greatest share in providing the respondents with scientific information with the mean score of 3.64 followed by the Internet, non-academic books and magazines and newspapers, and the satellite with the mean scores of 2.81, 2.18 and 2.06, respectively. The radio obtained the lowest rank in providing the respondents with information and scientific knowledge.

Table 6. Frequency distribution (\%) of the use of mass media

\begin{tabular}{|c|c|c|c|c|c|c|}
\hline $\begin{array}{l}\text { Frequency }(\%) \\
\text { Mass media }\end{array}$ & At all & Little & Average & A lot & Total & $\begin{array}{r}\text { Mean } \\
1-4 \text { scale }\end{array}$ \\
\hline $\begin{array}{l}\text { Non-academic books, } \\
\text { magazines and newspapers }\end{array}$ & 82 & 33 & 32 & 7 & 100 & 2.18 \\
\hline $\begin{array}{r}\text { General and science TV } \\
\text { broadcasts }\end{array}$ & 8.1 & 10.2 & 58.4 & 40.1 & 100 & 3.64 \\
\hline Satellite & 40 & 26.2 & 20.2 & 13.3 & 100 & 2.06 \\
\hline The Internet & 21 & 12 & 31.2 & 35.8 & 100 & 2.81 \\
\hline The radio & 60 & 20 & 10 & 10 & 100 & 1.7 \\
\hline $\begin{array}{r}\text { The use of mass media } \\
\text { (Total) }\end{array}$ & 26.99 & 23.34 & 26.55 & 23.1 & 100 & 2.5 \\
\hline
\end{tabular}

The total scores of the respondents were standardized on a 0-100 scale in order to compare the statistical data on the dimensions of PUS and the use of mass media. The mean scores of the respondents were then calculated on the new scale and considered as the scale average as illustrated in Figure 4.

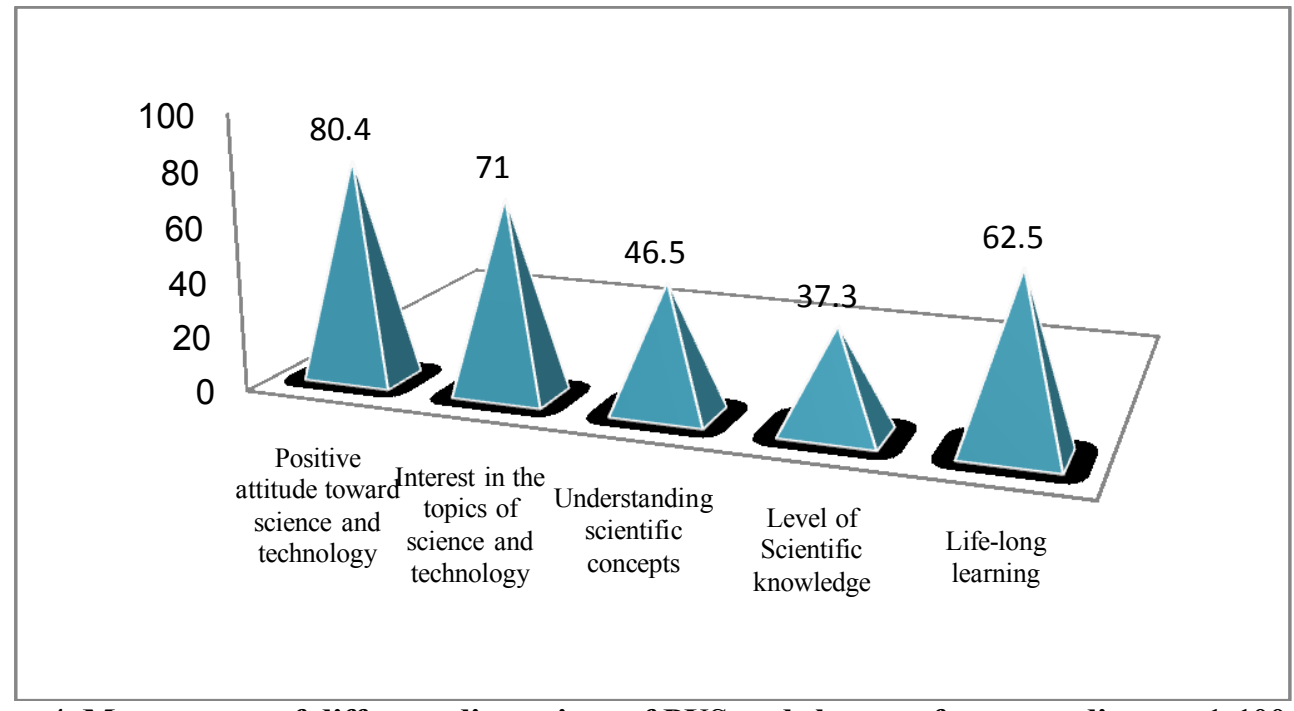

Figure 4. Mean scores of different dimensions of PUS and the use of mass media on a 1-100 scale

The mean scores of all dimensions of PUS were higher among the mass media users, which is clearly illustrated in Figure 5. 


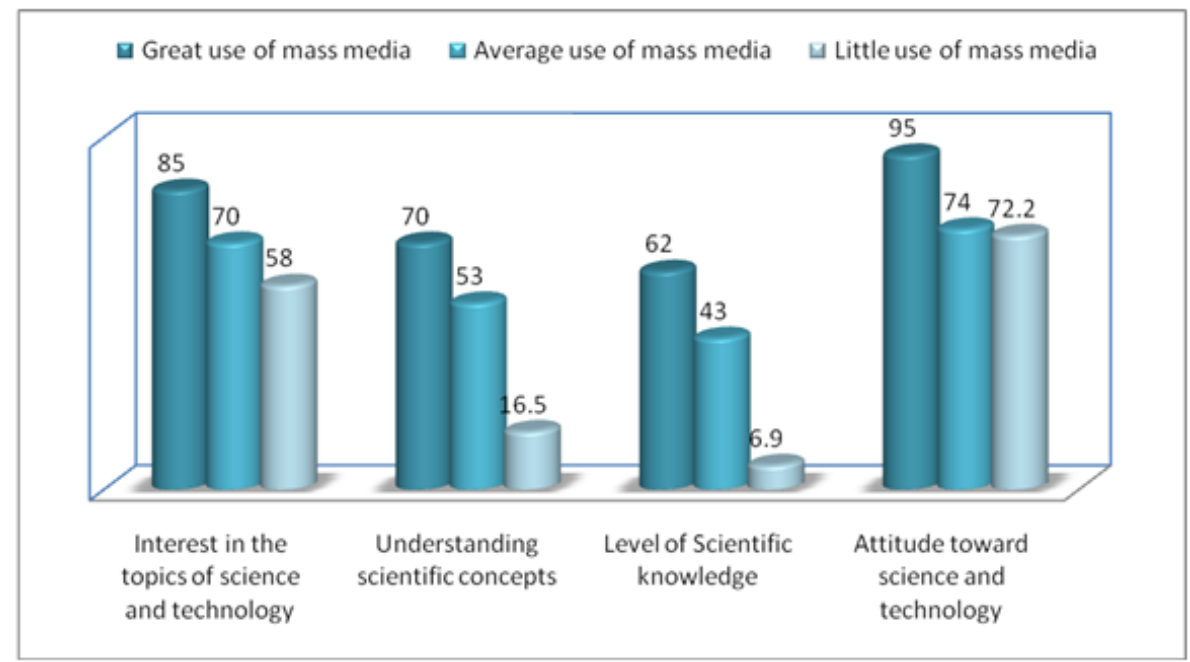

Figure 5. Mean scores (on a scale of 1-100) of different PUS dimensions among the groups using different mass media in different proportions

\section{5-6) Structural equation modeling}

Structural equation modeling was used to test the first research hypothesis in Amos software. Structural equation modeling has higher methodological exactitude comparing with conventional statistical tests of data analysis such as Pearson or Spearman correlation coefficients, linear regression, path analysis, etc because it deals with the latent variables (PUS and the use of mass media) as the constructs whose measurement entails errors. In other words, it includes the measurement errors of the variables in calculating the effect of the independent on the dependent variable (Ghasemi, 2010).

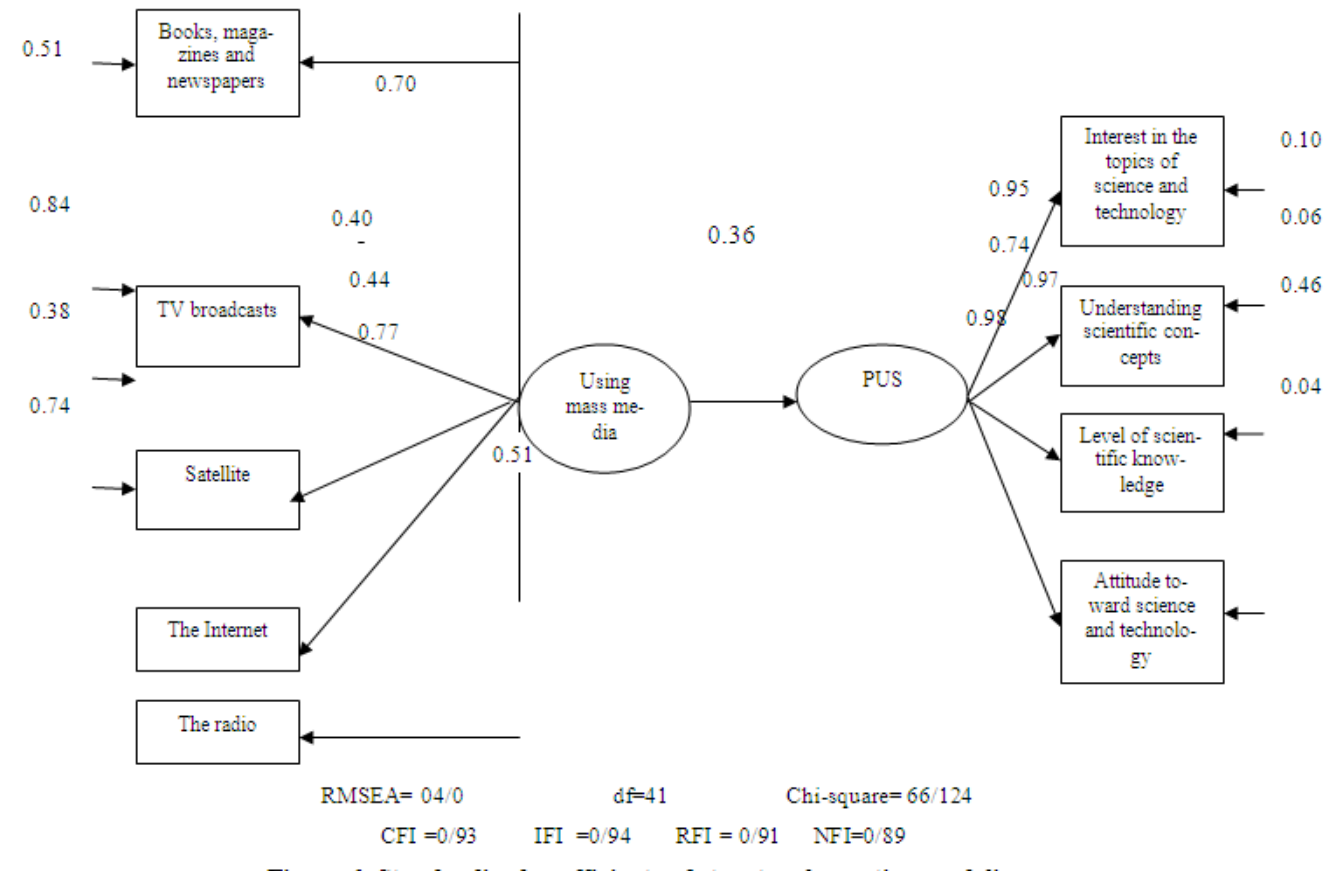

Figure 6. Standardized coefficients of structural equation modeling

The fit indices of the model show that it has goodness of fit. Since RMSEA value is smaller than 0.08 and NFI value is 0.89 and close to 1 , we can confirm the developed model. Other indices such as Incremental fit index (IFI) and CFI values were larger than 0.9. Thus, the developed model has goodness of fit and is supported by the data obtained from the population. The $t$-value of all standardized coefficients in the model were larger than 1.96. Therefore, all standardized coefficients written on the arrows are significant. 


\section{Discussion and conclusion}

The present findings revealed that the general public is interested in gaining knowledge. The mean score of the respondents' interest in scientific issues was above the average. The citizens were found to have a completely positive attitude toward science and technology so that the mean score of their attitude was 80.4 on a scale of 1-100. However, the results indicated that the respondents had low levels of scientific knowledge and limited understanding of scientific concepts. This indicates the exiting gap between knowledge and attitude. This is consistent with the findings of Ghanei Rad and Morshedi (2011).

The findings are more provocative, though, with regard to why and how individuals learned science. The findings strongly reinforce the mass media as important source of science learning.

When asked how they came to be knowledgeable in the identified area of science, the majority ( 40 percent) claimed to have learned their science and/or technology during watching television, and 36 percent of People described learning science by using the Internet.Although school was frequently mentioned as an important source of scientific learning, it was not the primary source for most people.

Informal education resources such as books, television and Mass media were reported utilized as frequently, or more frequently, than were formal education resources, which reinforces data collected by the US National Science Board (1998) indicating widespread utilization of mass media as informal science education resources. The National Science Board study found that 50 percent of American adults read a daily newspaper including articles on science, 15 percent read one or more science magazines each month, and a majority of Americans watched one or more science television shows each month. Approximately two-thirds of adults visited a science or natural history related museum, zoo, aquarium or park at least once a year and a third of Americans reported that they had purchased at least one science book during the preceding year.

The present findings revealed that although science subject is taught at school and university, what people know is not restricted to their formal education. In fact, people attach the same impotence to other sources as formal education. We do not mean to undermine schooling and formal science leaning, however. Although it seems that science education at school does not shape specific scientific knowledge in people, there is no doubt that focal and formal science education brings its benefits. Science education at school and university provides a foundation for the learner on which to further his/her personal and more special knowledge. Learners usually learn the basic principles of biology, physics and chemistry at school that is difficult to learn on free choice through self-study. However, it is only a need, motivation or curiosity that reinforces this basic knowledge to be applied in daily activities. This specific knowledge is enhanced, deepened and operationalized by mass media and the Internet.

We live in a world where information is so plentiful, most of us tend to specialize and focus on a few areas: in fact, it is impossible to be knowledgeable in all areas (Miller, 2001). For example, most physicists know very little about biology and most social scientists know little about physics. A Nobel laureate in chemistry, who for obvious reasons was not named, once confessed that he had never heard of plate tectonics before being awarded the prize (Pool, 1991). We live in a society where it is not uncommon for scientists to know little about the law (laws after all form the basis of our democratic society) and for attorneys to know little about science. Rather than seeing this as a failing of scientists or as evidence of the inadequacy of attorneys, this most likely reflects the information/knowledge realities of our age. We would hypothesize, though, that if a scientist were sued (or has read a recent John Grisham novel on that topic), he or she would learn something about tort law.

Similarly, we would hypothesize if an attorney were diagnosed with heart disease (or has read a scientifically accurate novel that deals with this topic), he or she would learn about the cardiovascular system and the relationship between diet, exercise, stress and cardiovascular health.

No doubt, the success of our society in future depends on our understanding of where, how, why and with whom people develop their scientific knowledge in their lifetime. To answer this question, the present findings crystalized the important role of informal sources and mass media. This finding supports the "contextual model" in PUS studies. Gaining a deeper understanding of how, when, where, why and with whom people develop their scientific knowledge helps science policy makers devise strategies and improve science and technology learning based on people's needs and interests. The present findings provide preliminary evidence to recognize and support the important role of non-school resources in learning science. The important role of mass media has historically been undermined and placed at a lower level of significance. However, considering the present findings, free-choice learning is the main tool for science learning and mass media are the best source of learning science. As discussed in this article, facts surrounding long-term learning shows that both formal schooling and informal learning (through mass media) have potentially a great share in teaching science to citizens. Research has shown that the more these two sources overlap, the more people will succeed in long-term science learning (Anderson, 1999; Hacker \& Harris, 1992; Nepp, 1997; Medrich, 1991; Wright et al, 2001).

Although public debates on science typically end with blames on formal course books due to their insufficient coverage of scientific knowledge, it appears that another attitude may be adopted as well. The weak- 
ness in scientific knowledge in society may relate to the weakness in understanding life-long nature of science learning, which results from insufficient financial support of all resources that contribute to science learning. The aim of teaching science in the twenty-first century and in the learning society is to provide full support for life-long science learning. Achieving this goal requires attention to personal needs of very citizen in his/her lifetime for learning. To attain this goal, parallel and supplementary support should be provided for both formal and informal learning.

\section{References}

[1]. Anderson, D. (1999) "Understanding the Impact of Post-visit Activities on Students' Knowledge Construction of Electricity and Magnetism as a Result of a Visit to an Interactive Science Centre," Unpublished doctoral dis-sertation, Queensland University of Technology, Australia.

[2]. Anderson, D., Lucas, K., Ginns, I. and Dierking, L.D. (2000) "Development of Knowledge about Electricity and Magnetism during a Visit to a Science Museum and Related Post-visit Activities," Science Education 84(5):658-79.

[3]. Fortner, R. (1986). Relative effectiveness of classroom and documentaryfilm presentations on marine mammals. Journal of Research in Science Teaching, 22, 115-126.

[4]. Ghanei Rad, M.A., Morshedi, A. (2011) “A Survey of Public Understanding of Science and Technology, A case Study on Tehran Citizens," Science and Technology Policy, 3(3):93-110.

[5]. Ghasemi, V. (2010) "Structural Equation Modeling Using Amos Software," Tehran: Jame-e Shenasan.

[6]. Ghazi Tabatabaie, M., Dadhir, B.A. (2007) "Sociology of Science-Technology: Pondering over Recent Changes in the Sociology of Science," Letter of Social Sciences $21(86)$..

[7]. Mulkay, M. (1997) "Science and the Sociology of Knowledge," Kachoian, H. (Trans.). Tehran.

[8]. , Individual learning accounts and other models of financing lifelong learning, International journal of lifelong education, vol 26,no1,pp5-23.

[9]. -American Association for the Advancement of Science (1994) Benchmarks for Science Literacy. New York: Oxford University Press

[10]. -Anderson, D. (1999) “Understanding the Impact of Post-visit Activities on Students' Knowledge Construction of Electricity and Magnetism as a Result of a Visit to an Interactive Science Centre," Unpublished doctoral dissertation, Queensland University of Technology, Australia.

[11]. - -Berendsen, M.L. (2003) "Conceptual Astronomy Knowledge among Amateur Astronomers: Implications for Outreach Training," Unpublished Masters Thesis, University of Western Sydney, Australia.

[12]. -Berendsen, M.L. (2005) "Conceptual Astronomy Knowledge among Amateur Astronomers," The Astronomy Education Review 1(4): $1-18$

[13]. -Brown, B.A., Reveles, J.M. and Kelly, G.J. (2005) "Scientific Literacy and Discursive Identity: A Theoretical Framework for Understanding Science Learning," Science Education 89: 779-802.

[14]. -Brown, J.S., Collins, A. and Duguid, P. (1989) "Situated Cognition and the Culture of Learning," Educational Researcher 18(1): $32-42$.

[15]. -Carlson, M.B. (1988) Meaning-Making: Therapeutic Processes in Adult Development. New York: W.W. Norton \& Company.

[16]. -Delanty, Gerard, 2003, citizenship as a learning process: disciplinary citizenship versus cultural citizenship, International journal of lifelong education, vol22, no6,pp597-605.

[17]. -Dirkx, J.M. (2001) The Power of Feelings: Emotion, Imagination, and the Construction of Meaning in Adult Learning. The New Update on Adult Learning Theory, vol. 89, pp. 63-72. San Francisco: Jossey-Bass.

[18]. -Driver, R.A. (1983) The Pupil as Scientist? Milton Keynes: Open University Press.

[19]. -Ellenbogen, K.M. (2003) "From Dioramas to the Dinner Table: An Ethnographic Case Study of the Role of Science

[20]. Falk, J.H. (2002) “The Contribution of Free-choice Learning to Public Understanding of Science,” Interciencia 27(2) :63-5.

[21]. -Falk, J.H. (2006) "The Impact of Visit Motivation on Learning: Using Identity as a Construct to Understand the Visitor Experience," Curator 49(2): 151-66.

[22]. -Falk, J.H. and Dierking, L.D. (1992) The Museum Experience. Washington, DC: Whalesback Books

[23]. -Falk, J.H. and Dierking, L.D. (2000) Learning from Museums: Visitor Experiences and the Making of Meaning. Walnut Creek, CA: AltaMira Press.

[24]. -Falk, J.H. and Dierking, L.D. (2002) Lessons without Limit: How Free-choice Learning is Transforming Education. Walnut Creek, CA: Alta Mira Press.

[25]. -Falk, J.H. and Storksdieck, M. (2005) "Using the Contextual Model of Learning to Understand Visitor Learning from a Science Center Exhibition," Science Education 89: 744-78.

[26]. -Falk, J.H., Brooks, P. and Amin, R. (2001) "Investigating the Role of Free-choice Science Learning on Public Understanding of Science: The California Science Center L.A.S.E.R. Project," in J.H. Falk (ed.) Free-choice Science Education: How We Learn Science Outside of School, pp. 115-32New York: Teachers College Press.

[27]. -Gerbner, G., Gross, L., Morgan, M., \& Signorelli, N. (1981). Scientists on the TV screen. Culture and Society, 42, 51-54..

[28]. -Gunter, B., Clifford, B. R., \& McAleer, J. L. (1997). Learning from multi-topic science programmes on mainstream television. Medienpsychologies: Zeitschrift für Individual and Massenkommunikation, 9, 3-23.

[29]. -Hacker, R. and Harris, M. (1992) “Adult Learning of Science for Scientific Literacy: Some Theoretical and Methodological Perspectives," Studies in the Education of Adults 24(2): 217-24.

[30]. -Halford,J.2006, the role of lifelong learning in building citizenship: European union approaches in the light of British and colonial experience, International journal of lifelong education, vol25, no3,pp321-332.

[31]. -Heimlich, J., Bronnenkant, K., Barlage, J. and Falk, J.H. (2005) Measuring the Learning Outcomes of Adult Visitors to Zoos and Aquariums: Phase I Study. Unpublished technical report. Bethesda, MD: American Association of Zoos and Aquariums.

[32]. -Jones, D. and Stein, J.K. (2005) The Flandrau Science Center Front-End Evaluation. Unpublished technical report. Annapolis, MD: Institute for Learning Innovation.

[33]. -Kelly, G.J. and Brown, C.M. (2003) "Communicative Demands of Learning Science through Technological Design: Third Grade Students' Construction of Solar Energy Devices," Linguistics \& Education 13: 483-501.

[34]. -Kretzmann, J.P. and McKnight, J.L. (1993) Building Communities from the Inside Out. Evanston, IL: The Asset-Based Community Development Institute, Northwestern University.

[35]. -LaFollette, M. C. (1990). Making science our own: Public images of science,1910-1955. Chicago: University of Chicago Press. 
[36]. -Latour , B , 1993 , "We have never been Modern", London : Harvester wheat sheaf

[37]. -Latour, b, 2005, reassembling the social: an introduction to actor- network Theory, Newyork, oxford university press.

[38]. -Mares,M. L.,\&Cantor, J. (1999). Using television to foster children's interest in science. Science Communication, 20, 283-297.

[39]. -Martin, Lan, 2003. Adult education, lifelong learning and citizenship : some ifs and buts. International journal of life long education, vol22, no6,pp566-579.

[40]. -McCombs, B.L. (1991) "Motivation and Lifelong Learning," Educational Psychologist 26: 117-27

[41]. -Medrich, E.A. (1991) "Young Adolescents and Discretionary Time Use: The Nature of Life Outside of School," Paper commissioned by the Carnegie Council on Adolescent Development for its Task Force on Youth Development and Community Programs.

[42]. - -Miller, J.D. (1987) "Scientific Literacy in the United States," in D. Evered and M. O'Connor (eds) Communicating Science to the Public, pp. 19-40. London: Wiley.

[43]. -Miller, J.D. (1998) "The Measurement of Civic Scientific Literacy," Public Understanding of Science 7: 1-21.

[44]. -Miller, J.D. (2001) “The Acquisition and Retention of Scientific Information by American Adults,” in J.H. Falk (ed.) Free-choice Science Education: How We Learn Science Outside of School, pp. 93-114, New York: Teachers College Press.

[45]. -Miller, J.D. and Pifer, L. (1996) "Science and Technology: The Public's Attitudes and the Public's Understanding," in National Science Board, Science and Engineering Indicators: 1996, pp. 7.1-7.21. Washington, DC: US Government Printing Office.

[46]. -Miller, S. 2001. Public understanding of science at the crossroads. Public Understanding of Science10:115-120.

[47]. -Museums in Family Life," Dissertation Abstracts International 64(03): 846A (University Microfilms No.AAT30-85758).

[48]. -National Science Board (1998) Science and Engineering Indicators: 1998. Washington, DC: US Government Printing Office.

[49]. -National Science Board (2000) Science and Engineering Indicators: 2000. Washington, DC: US Government Printing Office.

[50]. -National Science Board (2002) Science and Engineering Indicators: 2002. Washington, DC: US Government Printing Office. Falk et al.: Importance of free-choice learning 467

[51]. -National Science Board (2004) Science and Engineering Indicators: 2004. Washington, DC: US Government Printing Office.

[52]. -Nelkin, D. (1995). Selling science: How the press covers science and technology.

[53]. New York: Freeman.

[54]. -Pollack, A. (1998, December 1). Scientists seek a new movie role: Hero not villain. The New York Times, p. F1.

[55]. -Pool, R. (1991) "Science Literacy: The Enemy Is Us," Science 251: 266-7.

[56]. -Pope, M. and Gilbert, J. (1983) "Personal Experience and the Construction of Knowledge in Science," Science Education 67: 193203

[57]. -Roth, W.M. and Lee, S. (2002) "Scientific Literacy as Collective Praxis," Public Understanding of Science 11: 1-24.

[58]. -Strike, K. and Posner, G. (1992) “A Revisionist Theory of Conceptual Change,” in R.A. Duschl and R.J. Hamilton(eds) Philosophy of Science, Cognitive Psychology, and Educational Theory and Practice, pp. 147-76. Albany,NY: State University of New York Press

[59]. -Wright, J.C., Anderson, D.R., Huston, A.C., Collins, P.A., Schmitt, K.L. and Linebarger, D.L. (2001) “The Effects of Early Childhood TV-viewing on Learning," in J.H. Falk (ed.) Free-choice Science Education: How We Learn Science Outside of School, pp. 79-92. New York: Teachers College Press. 